Brandeis $\left.\right|_{\text {urearar }}$

brandeis.edu/j-caste
CASTE: A Global Journal on Social Exclusion

Vol. 2 No. 2 pp. 327-340

October-November 2021

ISSN 2639-4928

https://doi.org/10.26812/caste.v2i2.317

\title{
Exclusion of Tribal Women from Property Inheritance Rights: A Study of Tripuri Women of India
}

\author{
Ashim Shil' and Hemraj P Jangir²
}

\begin{abstract}
The Tripuri tribe from the state of Tripura constitutes around 50 percent of the total tribal population and can be found in all eight districts of the state. The tribe follows its own culture and tradition in terms of marriage and other customary practices. This study investigates the role of gender in inheritance of property among the Tripuri tribe and how Tripuri women are excluded from ownership of property. It also attempts to discover how property ownership affects their income and position in the household. The study has been conducted in the districts of West Tripura and Dhalai. Focus Group Discussion and interview schedules are employed as methods for collection of data.

Results show that while 20 out of 54 married women from rural areas of West Tripura have inherited property, only 2 out of 13 married women have inherited property in the urban area. In comparison with West Tripura, Dhalai features a low ratio among women in inheriting property (only 4 out of 38 married women). A few causes include low level of literacy, slow urbanization and less inter-community marriages. The reasons for not inheriting property include: a woman failing to live up to the concept of a 'good sister' in the brother's eyes, son needs property to care for parents, cost of marriage is borne by brother or parents so no right to claim, and to avoid unnecessary conflict in the family. In this manner, societal perceptions prevent women from claiming the legitimate share of their ancestral property.
\end{abstract}

\section{Keywords}

Tripuri tribe, Property rights, Exclusion and Social perception

'Ph.D, Research Associate, Women's Studies Centre, Tripura University, Suryamaninagr, Tripura ${ }^{2}$ Ph.D Scholar, Indian Institute of Dalit Studies (IIDS) New Delhi

E-mail: shilashim86@gmail.com

\section{*Corresponding Author}

Hemraj $P$ Jangir

E-mail: hemraj82339@gmail.com

(C) 202 I Ashim Shil et al. This is an open access article distributed under the terms of the Creative Commons Attribution License, which permits unrestricted use, distribution, and reproduction in any medium, provided the original author(s) and source are credited. 


\section{Introduction}

Tripura has a plural society consisting of a population belonging to diverse religious communities. The social structure is the result of cultural assimilation between tribal and non-tribal communities. The Tripuri community is the largest ethnic group among the nineteen tribes residing in Tripura. They are scattered amongst the eight districts and constitute 50.76 percent (Census of India, 2011) of the total tribal population of Tripura. The participation of tribal women in agriculture is a longstanding surviving practice or tradition in Tripura. The Tripuri community follows their own traditions, customary laws, and practices in marriages, childbirth ceremonies, death rituals, and cultivation rituals. But interestingly they do not have any specific custom for property inheritance.

This tribal community adopted settled cultivation and in the context of government policies to abolish the practice of jhum or shifting cultivation, land rights emerged as crucial. In recent times, Forest Right Act (FRA) has become a significant tool to confer land rights to tribal forest dwellers. Land ownership documents are often mandatory to access the benefits of different government schemes based on land, credit from the bank, etc. Both land ownership and adequate housing are necessary for the full realization of human potential. The Universal Declaration of Human Rights, Article 17, states: "Everyone has the right to own property alone as well as in association with others; No one shall be arbitrarily deprived of his property."

In this context, it becomes relevant to identify the pattern of land ownership and how Tripuri women are excluded from inheritance of land ownership.

\section{Patterns of Property Ownership among Tripuri Community}

There are various accounts of intergenerational property transfers and gender plays a significant role in this process. This section deals with the role of gender in accessing inheritance of property rights among women in general and Tripuri women in particular. This section also explores the contrasts in access to property rights and related issues. Inheritance among Tripuris devolves from father to son and the eldest son generally gets the major share (Deb Barman, 1983; Bhowmik, 2003; Barooah, 2009). According to Tripuri customary laws and practices, the male is the absolute owner of family property, whether self-acquired or inherited and he holds the right to dispose any such property (Barooah, 2009). The father distributes his property between the sons in his old age to avoid possible disputes after his demise. Sometimes, the father is pressurized by the adult sons to distribute the property. On occasion, the incapability of the father to look after his property forces him to divide the property among his adult sons. But in many cases, the property is partitioned after the death of the father. In some instances, it has been found that after the death of the father, his sons inherit two-thirds of the property and the remaining one-third is distributed equally between the mother and daughters. If the mother's property is registered, then the daughter becomes the legal inheritor of her mother's property. If a Tripuri man has more than one wife, sons of the second wife also get an equal share of their father's property. The adopted son of a person also has the right to inherit his foster father's property (Bhowmik, 2003). 
The Human Rights Resolution 2005/25 aspires for women's equal ownership, access and control over land. It also advocates that the equal right to own property and adequate housing are necessary for the full realization of human potential. The right to property, especially the right to inheritance of property is one of the most debatable rights because of its association with the political, economic, cultural and religious belief of a nation. In rural India, less than 2 percent of women inherit landed property (Lahoti \& Swaminathan, 2016).

It has been argued by Agarwal (2003) that though the legitimate share of land property is a significant entry point to the empowerment of women, in reality the gender-based constraints on society influence the accessibility of women to their legitimate share of property rights. Often, the community and customary practices also discourage women from accessing their right to landed property, especially among the tribal women. Tribal women across geographical boundaries are usually governed by customary laws and practices and continue to be deprived of ownership of property especially through inheritance rights. Sometimes, these customary laws are in contradiction with the constitutional laws and court interventions uphold gender equality in access to property ownership of women. The argument for ownership of land or property by women rests on the premises that (a) it is her right to inherit parental or husband's property (b) ownership of property acts as a security for women (c) property ownership also improves her position in the household and improves her entitlement to income.

\section{Social Exclusion}

The concept of Social Exclusion emerged in academic discourse recently and it correlates with poverty, inequality and socio-economic injustice (Kabeer, 2000). Silver (2011) opined that "social exclusion is nothing but an active relationship between two group i.e. excluders and excluded", the former use specific mechanism(s) to push the latter out and deny them equal access to resources. Thorat (2013) defined social exclusion as the denial of equal opportunities. He says, "it is an unfair practice that being imposed by a social group upon another which leads to inability among latter group to participate in the political, economic and social aspects of the society". Therefore, social exclusion can be explained as a process through which one group excludes another from equal access to social, economic and political resources on the basis of their group identity. And in turn, it leads to poverty, loss of status in society, lack of recognition and also humiliation of the excluded group.

There is a need to understand the concept of social exclusion from the perspective of tribe and gender. Therefore, the present study is an attempt to deal with the issue of social exclusion from the perspective of tribal women of Tripura. Though there exist several studies on issues faced by the tribes of Tripura, there is hardly any discussion on the property rights of tribal women. Thus, this article attempts to trace the exclusion of property ownership among the Tripuri women and the role of gender in this context.

\section{Research Methodology}

A field survey was conducted in the West Tripura district and Focus Group Discussions (FGDs) conducted in Dhalai district of Tripura. The survey area was selected purposefully to include urban and rural areas, so that a suitable sample of Tripuri urban 
and rural households maybe obtained. Survey and FGDs are used as methodological tools to assess the circumstances of Tripuri women with respect to property rights. The population of West Tripura district is predominantly non-tribal and intermixing between the two communities is commonplace. Tribals could follow and speak in Bangla, Hindi or English. Individual interviews of 78 selected Tripuri women from Takarjala, Mohanpur, Champaknagar and Agartala were conducted using a semistructured interview schedule.

However, individual interviews could not be conducted in Gandachara in Dhalai district as the tribal women were unwilling to communicate with outsiders. Gandachara is one of the most remote places where the population is predominantly tribal, speaking only in local Kokborok. Communication with the women individually proved to be difficult even in the presence of interpreters from their community. However in a group, they were found to be communicating well. In this circumstance in Gandachara, we have conducted FGDs in four villages; these are Taraban, Pakhi Tripura Para, Bhagaban Tilla and Ratha Para where 38 women participated in the FGDs.

The article consists of three sections. The Introductory Section I states the objectives and describes the methodology followed. Section II describes the pattern of property ownership among Tripuri community and the contemporary debates on gender-based constraints in access to the rights of property ownership. Section III presents the findings of the field survey and makes concluding observations.

\section{Result}

Of the 78 Tripuri women surveyed from selected rural and urban households of West Tripura district, 38 women, i.e. 48 percent are found to have property of their own.

As noted in NFHS (2015-16), in Tripura, 57.3 percent women from all communities own houses or land individually or jointly with others (NFHS-4). A reason for the high percentage of land-ownership among women might be attributed to the Amended Hindu Succession Act (2005). Even Amaral (2017) identified the causal effect of improved inheritance rights on women's wellbeing by utilising an exogenous change in inheritance legislation that impacted India's Hindu society: the Hindu Succession Act (HSA). Our field survey discovered three types of landowners: women with inherited property, purchased land in their names and joint pattas on land.

Among the 54 married women of the sample from rural areas of West Tripura district, 20 women (37 percent) have inherited property. One of the four widows in the sample inherited parental and conjugal property. Two deserted women received support from their parents in terms of share in property. In contrast, urban areas of West Tripura district only have two (2) out of thirteen (13) married Tripuri women with inherited property.

However, we discovered a different picture in Dhalai district. From the 38 Tripuri women who participated in the FGDs, only four (10 percent) women have inherited property. Twenty-five women accrued property through patta (deed) under land distribution programme of the government or FRA, 2006. These 25 women (65 percent) have received the joint pattas of forestland. The remaining 9 women (23 percent) stay in the Khash land. None of the women have purchased land. 
Table I: Sample distribution on marital status, income and education in West Tripura district

\begin{tabular}{|c|c|c|c|c|c|c|}
\hline S. No. & & West & ripura Distr & & & \\
\hline \multirow{5}{*}{ I } & \multirow{5}{*}{ Marital Status } & & $\begin{array}{c}\text { Gram } \\
\text { Panchayat }\end{array}$ & $\begin{array}{l}\text { ADC } \\
\text { Village }\end{array}$ & Corporation & Total \\
\hline & & Married & 24 & 30 & 13 & 67 \\
\hline & & Unmarried & 2 & 0 & 1 & 3 \\
\hline & & Deserted & 2 & 0 & 0 & 2 \\
\hline & & Widow & 2 & 2 & 2 & 6 \\
\hline \multirow[t]{6}{*}{2} & \multirow[t]{6}{*}{$\begin{array}{l}\text { Source of } \\
\text { Income }\end{array}$} & $\begin{array}{l}\text { Agriculture/Animal } \\
\text { husbandry }\end{array}$ & 6 & 17 & 0 & 23 \\
\hline & & Daily wage labourers & 7 & 2 & 0 & 9 \\
\hline & & Government job & 10 & 0 & 5 & 15 \\
\hline & & Private job & 2 & 0 & 0 & 2 \\
\hline & & Other & I & 6 & 3 & 10 \\
\hline & & Housewife & 4 & 7 & 8 & 19 \\
\hline \multirow[t]{6}{*}{3} & \multirow{6}{*}{$\begin{array}{l}\text { Educational } \\
\text { qualification }\end{array}$} & Post graduate & 3 & 0 & 1 & 4 \\
\hline & & Graduate & 3 & 0 & 2 & 5 \\
\hline & & Higher secondary & 5 & I & 3 & 9 \\
\hline & & Secondary & 6 & 4 & 6 & 16 \\
\hline & & Primary & 12 & 20 & 4 & 36 \\
\hline & & Adult literacy & I & 7 & 0 & 8 \\
\hline
\end{tabular}

Source:Authors, based on fieldwork, 2019

According to our data, in Dhalai district a reason for low inheritance is that the concept of inherited property has not developed among the Tripuri community as it has in West Tripura district where literacy, urbanization and inter community exchanges are prevalent. In our study area at Dhalai, the Tripuri communities for generations inhabit forestland, so they do not have any individual property as such. One woman (55 years of age) expressed her views in FGD:

I got married under the Dafa Rang custom where my husband gave ₹600 as bride price to marry me. I along with my two sisters did not get any property through inheritance. The reason behind not getting inheritance of property was the mindset that after marriage women are not entitled to inherit property. I did not get any patta land for survival. I have no children and I am staying with one of my sisters. I maintain her expenses through the amount I am getting on social security pension and MGNREGA. I am unaware of the legislation of equal rights of women to inherit parental property. But my perception is that if such law is there then it reduces the tension between family members and everybody can be happy.

Ownership of property is expected to ensure a better life to the women by providing security of income and food safety and also enabling them to participate in household 
decision-making. The types of landed property that women inherit also reflect gendered practices. Usually women receive inferior land as their share in parental property (Agarwal, 1994).

However, as shown in the Table 2, Tripuri women received productive land or property through inheritance. Yet none of them are found to use the property because those happened to be located at a distance far from their residence.

A woman may have the legal right to inherit property, but if the law is not enforced or the claim is not socially accepted, it may remain merely on paper. It is commonly observed that the patriarchal family structure puts pressure on women to give up their share in order to benefit the male counterpart.

Table 2: Types of inherited property of Tripuri women in West Tripura district

\begin{tabular}{|l|c|}
\hline \multicolumn{1}{|c|}{ Types of land } & Number of owner(s) \\
\hline A part of house & 4 \\
\hline A plot of in commercial area & 2 \\
\hline A plot of plain land & 6 \\
\hline Agricultural land & 7 \\
\hline Rubber plantation & 1 \\
\hline Tilla and Jungle & 5 \\
\hline Total persons & 25 \\
\hline
\end{tabular}

Source: Field Survey, 2019

\section{Reasons for not inheriting property}

As mentioned in the discussion on West Tripura district, inheritance is the main method of property ownership for women. Further investigations revealed additional reasons why many women did not inherit property. See Figure 1.

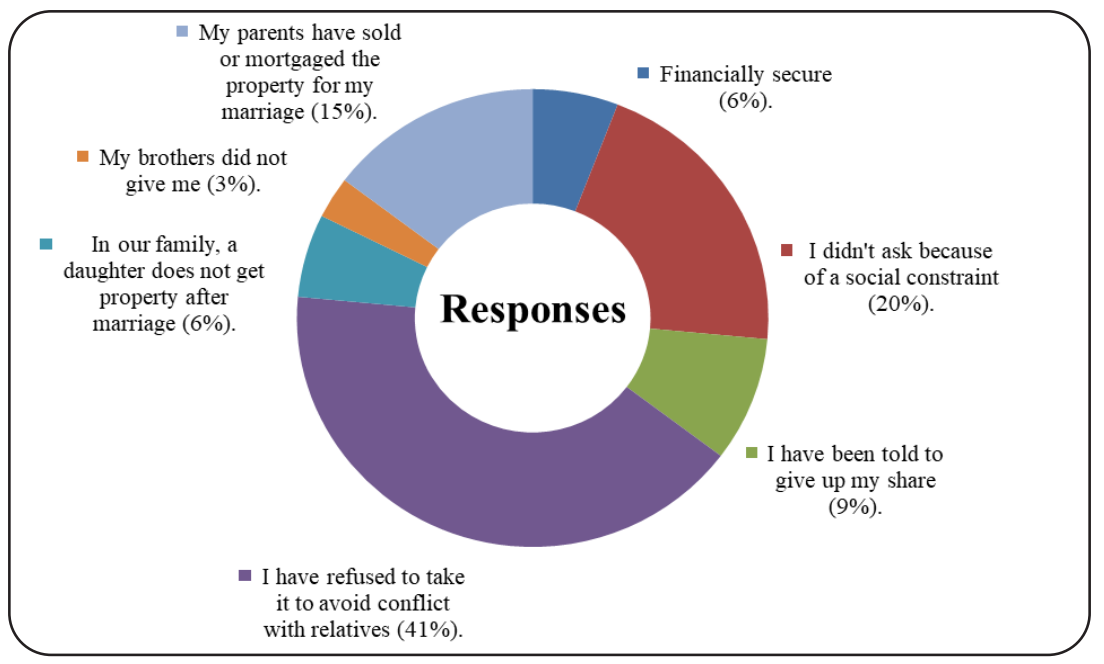

Figure I: Reasons for women not inheriting property

Source: Field Survey, 2019 
These reflect the deeply entrenched social taboos against women claiming a share in parental property. In this study, we found that 41 percent women of the Tripuri community did not claim or gave up their claim to inherit their ancestral property. A primary reason for doing so in favour of their brothers was to be a 'good sister'. Another reason is that in a society like the Tripuri community, when a bride moves to her in-law's house after marriage, then it is assumed that the sons will live with the parents and take care of them. Therefore, the property would go to the sons as a means of financial support for their elderly parent's care. Sometimes the lack of social security for women compels them to see brothers as the source of security, especially in case of a marital dispute. In effect, indicating that legal rights in the inheritance of property do not guarantee the actual rights on it. Another reason for not demanding the ancestral property is the cost of marriage. In Tripuri society, dowry is generally not practised but it is a common social practice to give gold and jewellery, furniture and other gifts to the newly-wedded couple. They also incur huge costs to arrange food and wedding expenses towards relatives and community members. The family of the bride often has to sell or mortgage their land property to meet the expenditure given social expectation. Thus, at the time of property distribution, the marriage cost is counted as the cost of property the daughter or sister was supposed to get. Our study indicated that 15 percent of the women surveyed had given up their share in parental property on the pretext of the expenditure incurred during their marriage.

\section{Property Rights and Economic Well-being of Tripuri Women}

Apart from inheritance, another way to acquire property is through purchase. It is interesting to note that both in urban and rural areas about 19 percent of Tripuri women are found to be owners of land which has been purchased. In urban areas, only 3 out of 16 women (18 percent) have purchased land. In rural areas, 12 out of 62 (19 percent) women are owners of purchased land. However, they do not have de facto rights on the property as the land was purchased by their husbands in their names. They are owners in name only. Our field survey revealed interesting facts in both the rural and urban contexts.

Several tribal women became land owners through government programmes. In West Tripura district, 13 out of 52 women, i.e. 24 percent married women, have received patta of forestland in the Tripura Tribal Areas Autonomous District Council (TTAADC) areas jointly with their husbands. Conferring user rights to forestland by issuing joint pattas to the households by the government is likely to exclude single women who are widowed or deserted or are unmarried and living alone. A 65-year-old widow narrated her story as below:

I have five siblings including three sisters. I also got married under the Dafa Rang custom where my husband gave Rs 500 as bride price to marry. I, along with other siblings, did not receive any property through inheritance as my father has no property. We used to stay in the forest land and jhum cultivation was our main source of survival. So, the concept of inheritance does not arise to us.

This widow received 3.5 acre of patta land from the government. However, this land is about $8-10 \mathrm{~km}$. from her place of residence. For that reason, her land is cultivated by her daughter who is a deserted woman. Jhuming on that patta land is the main 
source of survival for her and her daughter. Her daughter ploughs the patta land, shares the crops and grains such as rice, chilli and til (sesame seeds) with her widowed mother. She also shares the amount that she earns by selling other jhum products and ensures monetary support for her mother. A woman with land in her name does not only aid the landholder, but it also gives financial support to other women in a similar crisis situation.

In Dhalai district, where about 65 percent women have received joint patta, only 18.18 percent women are involved with productive activities like rubber, betel nut plantation, etc., and are earning a sum of around Rs 20,000-25,000 per annum. Amongst the patta holders, 41 percent are unable to perform any productive activity due to lack of funds. Very few respondents applied for loan against patta.

It is also found that those who have received the loan spent the amount to purchase motorcycles, make payments for the marriage of a daughter or for other purposes. Most of them are reluctant to take loans as they are apprehensive of the banking system and are afraid that would not be able to repay the loan. Our survey indicated that they have limited level of understanding on the banking system and they do not want to entertain the complications of administrative process. They said, "If we take a loan, then how will we repay the loan? And also we do not have much understanding about the banking system." If they are unable to repay the loan, then they will have to deal with the police or bankers. Except jhuming or daily wage work they have few alternative sources of earning.

\section{Property Inheritance Right and Marital Choice}

In communities where daughters are allowed to marry within the close kin or cross cousins, there is a greater possibility of land remaining in the hands of the natal family. Therefore, in such communities it is seen that the property inheritance by daughters is less or they are given the responsibility to work on the field (Agarwal, 1994).

Table 3: Inheritance of ancestral property and marital choice

\begin{tabular}{|l|c|c|}
\hline \multicolumn{1}{|c|}{ Category } & Own & Not Own \\
\hline Married within the community & 24 & 47 \\
\hline Married with in a different community & $\mathrm{I}$ & 4 \\
\hline Unmarried & 0 & 2 \\
\hline Total & 25 & 53 \\
\hline
\end{tabular}

Source: Field Survey, 2019

In many communities, including the Tripuris, marriage between different communities is not very common. If a woman gets married to someone from a different community, then there is a chance that she will forfeit her right to inheritance. Of the five Tripuri women marrying outside the community, only one got a share of parental property.

\section{Female Literacy and Property Ownership}

Literacy is one of the factors that affect a woman's ability to claim and manage land in several ways. For example, it can be one of the perimeters in women's knowledge of 
laws and legal rights, their capability to deal with official procedures in relation to land claims. Education also enhances their knowledge on new agricultural technologies and practices, self-confidence and bargaining power. Table 4 shows how the education levels of Tripuri women result in the inherited property registration in their names.

Table 4: Property registered and level of education

\begin{tabular}{|l|c|c|c|}
\hline \multicolumn{1}{|c|}{$\begin{array}{c}\text { Education level of the } \\
\text { respondents }\end{array}$} & $\begin{array}{c}\text { Inherited } \\
\text { property } \\
\text { registered }\end{array}$ & $\begin{array}{c}\text { Inherited property } \\
\text { not registered }\end{array}$ & Total \\
\hline Post graduate and above & $\mathrm{I}$ & 3 & 4 \\
\hline Graduate & $\mathrm{I}$ & $\mathrm{I}$ & 2 \\
\hline Higher secondary & 2 & 2 & 4 \\
\hline Secondary & $\mathrm{I}$ & 2 & 3 \\
\hline Upper primary & 2 & 5 & 7 \\
\hline Lower primary & 3 & 0 & 3 \\
\hline Illiterate & 2 & 0 & 2 \\
\hline Total women & 12 & 13 & 25 \\
\hline
\end{tabular}

Source: Field Survey, 2019

Table 4 shows a dichotomy in relation to the level of education and property registration. It shows that highly educated, i.e. only 1 out of 4 postgraduate women registered the inherited property in their name. Their reluctance to register their property is comparable to women with lesser level of education because either they are economically well off, or they are single daughter or they are staying at their parental home.

Property ownership and household decision-making power of women is also interlinked. There is a common perception that if women have much land then they can make more independent decisions on household issues or may act as the head of the household. In our study, out of 38 Tripuri women who are property owners, only six have the role of head of the household. It is interesting to note that all of them are either widowed or deserted. In the case of married women, the husband is the head of the household and it is the husband who makes all major decisions. Tripuri men have direct and indirect control and decision-making power in the family, even when women own property.

\section{Property Ownership and Domestic Violence}

Feminist scholars who have studied the Property Rights of Women have shown the correlation between violence, especially domestic violence, and women's property ownership. Amaral (2017) has expressed that the chances of inheriting property by women reduce conditions such as dowry payments, spousal violence, etc. A research study (Panda and Agarwal, 2005) indicates the correlation between ownership of property and violence against women. It is evident that 29 percent non-propertied women had experienced some form of physical violence and 49 percent women had experienced some form of psychological violence. The study also exposed that only 3 percent propertied women faced dowry-related violence. These two studies reflect that 
if women have property ownership, then the violence against them can be less than that faced by non-propertied women.

There is different information found in the National Family and Health Survey, 2015-16 where women have higher ownership of property, but spousal violence is also higher than in other states.

Table 5: Land ownership and domestic violence against women in India

\begin{tabular}{|l|c|c|}
\hline \multicolumn{1}{|c|}{ State } & $\begin{array}{c}\text { Land owned by } \\
\text { women (\%) }\end{array}$ & $\begin{array}{c}\text { Domestic } \\
\text { violence (\%) }\end{array}$ \\
\hline Manipur & 69.9 & 53.1 \\
\hline Andhra Pradesh & 44.7 & 43.2 \\
\hline Bihar & 58.8 & 43.2 \\
\hline Jharkhand & 49.7 & 34.0 \\
\hline Telangana & 50.5 & 43.0 \\
\hline Odisha & 63.5 & 35.2 \\
\hline Madhya Pradesh & 43.5 & 33.0 \\
\hline
\end{tabular}

Source: National Family and Health Survey, 2015-16

Table 5 indicates that in Manipur where women own the highest percentage of property, is also recorded the highest percentage of spousal violence. In Madhya Pradesh, domestic violence against women is lower than other states while property ownership of women is also low.

Two pertinent issues in this regard arise with Panda and Agrawal's claim. Panda and Agrawal (2005) look at violence as a dependent variable and study specific cases where both dependent and independent variables, i.e. property ownership and domestic violence are exclusive of each other. However, the NFHS 2015-16 data does not show any exclusive correlation about whether they are the same set of people or how many non-property owners are the victims. Our study shows related evidence discussed in Table 6.

Table 6: Property ownership and violence against Tripuri women

\begin{tabular}{|l|c|c|}
\hline \multicolumn{1}{|c|}{ Violence done by } & Propertied & Non-propertied \\
\hline In-laws & 4 & 0 \\
\hline Husband & 3 & 0 \\
\hline Both & 2 & 1 \\
\hline Total & 9 & 0 I \\
\hline
\end{tabular}

Source: Field Survey, 2019

Out of seventy-eight Tripuri women, we found that ten women faced domestic violence by the husband or in-laws. The data indicates that women ( 9 out of 10) have property in their name but incidents of domestic violence are not reduced. The question emerges on the actual control of women on land property. In reality we have seen that the purchase of land in the name of women normally depends on the initiative of men. Sometimes, to avoid the deed registration fee and government tax, women became the namesake-owners of the land. Figure 1 shows several gendered factors for women not inheriting property. Alcoholism, adultery, sexual dissatisfaction in married life may 
also increase the percentage of spousal violence against women. In contrast, we must remember that the fear of reporting to the police, fear of being made an 'outcast' from family and society, restrictions on women's movement, fear of marital breakdown and alternative shelter, lack of support from local administrations, lack of transportation, and the economic independence of women from other economic resources also reduces the percentage of reports of spousal violence against women.

\section{Discussion}

Rights are defined as claims that are legally and socially recognized and enforceable by an external legitimized authority. However, when the laws and legitimate authority are prejudiced by traditional gender roles and norms it is very difficult to enjoy those rights that have been confirmed for women. There are several ways in which women have the 'rights' in land property but stereotypically are denied access to the land. Inequality in access to land rises from social and cultural constructions of gender which affects women's rights especially in land. Rights in landed property are also positional and regional features. In many societies, cultivation is not women's work. It is predominately done by men. In several states in India, additional land is allowed to be cultivated only by adult sons but not by adult daughters (Agarwal, 1994). A woman may have the legal right to inherit property but this may simply be on paper if the law is not enforced or if the claim is not socially accepted. It is often observed that the patriarchal family structure puts pressure on women to forfeit her share in favour of the male counterpart.

It is commonly observed that when the husband dies, the widowed woman is given a lower position than the children. She is considered as 'beneficiary' and can be 'willed out' from her deceased husband's property (Agnes, 2009). This gender-based disparity in access to inheritance property of widowed women is not only restricted to the Santhal women, it is true for widowed women in general. The deep-rooted patriarchal notions of Indian society do not allow women to have landed property. Such norms however are by no means limited to India. The traditional gender performance and social customs have been preserved in modern laws in many countries. For example, Chinese law specifies that after a woman marries into another village, she should forego her share of land to the parental village and in return she would receive a share in the village or household she marries into (Kelkar, 2014). This patriarchal worldview that underwrites the property rights of women has been a subject of Bengali women's writings in British India. In the writings of Anurupa Devi (1949), the author argues that as men are the main bearers of a lineage, property should accumulate to them because women after their marriage move into different lineages, this property is best protected if it remains under male control. But in contrast, Saralabala Sarkar argued that the lack of property rights to women gives rise to a "slave mentality" amongst women. She also described women without property rights as "meek", "dependent" and "needy". Unless they are given property rights, they will not get the scope to learn the mastery over property (Majumdar, 2003). 
Another area of gender constraint that Nityo Rao points out is the pathetic situation of a Santhal woman of Dumka district of Jharkhand where she faced exceptional occurrences of gender-based barriers in relation to customs, marriage and property rights. A 32-year-old widowed woman faced social obstruction to plough her deceased husband's land by members of her marital house. The reason behind the social obstruction was that she had no son and she had no option to get married again because of the fear of losing her deceased husband's property (Rao, 2005).

Having legitimate guarantee on property rights generally means that the person has actual rights over landed property. However, in the case of women, it always follows the existing societal norms and values and ironically discourages women from asserting their right to inherit property. For example, the Maluki Ain community in Nepal only favours inheritance of property by the daughters if they are unmarried and above 35- years of age. Scholars like Bina Agarwal critically analyses these issues in her writings. According to her, from the lens of gender it is incorrect to assume that legal ownership carries the actual control of women on land. Many women let down their shares in paternal land in favour of their brothers to be a 'good sister'. It is common social practice that married women need the husband's consent to alienate her landed property and some communities like the Jaffna Tamils in Sri Lanka under the Sawalami Legal Code have made it a part of their customary code (Agarwal, 1994). Sometimes the lack of social security of a woman compels her to look to the brother as the source of security, especially in cases of marital dispute (Agarwal, 1994). The position of women in a family also indicates that the economic status of a woman cannot be judged by the economic status of her family. Without women's independent income sources, a woman cannot be independent in her rich parental or marital homes in case of widowhood and marital dispute (Agarwal, 1994). The household work, child and elderly care are still a woman's responsibility. The sexual mores and women's freedom of movement in Indian society indicates that the legal rights in inheritance of property do not guarantee the actual rights of women in inheritance of property in deed.

There is a correlation between female possession of property and violence against women. Data suggests that the violence against women in relation to access to their property rights is on the increase. A study (Panda and Agarwal, 2005) which looked at a sample of 502 women, found that only 34 percent women have owned immovable property, 29 percent non-propertied women had experienced some form of physical violence and 49 percent had experienced some form of psychological violence. The same study also exposed that only 3 percent propertied women faced dowry-related beating by her husband or in-laws, paralleled with 44 percent of the property-less. During a personal conversation with the Chairperson of Tripura Commission for Women on 21 January 2016 at her office, it came to be known that there are several cases of witch-hunting in Tripura that have been rooted in the desire to grab the landed property of women.

But surprisingly the Annual Report of Tripura Commission for Women (Annual Report, April 2013-March 2014) reported that not a single complaint of witchhunting was registered under the Commission. The report also shows that in terms of 
'Overview', the registered complaints (district-wise) in the Commission, the highest, i.e. twenty-two cases of property-related issues were registered from West Tripura district, while cases of domestic violence, matrimonial disputes or maintenance are also highest in West Tripura district (Annual Report, 2013-2014, pp. 18-19).

\section{Conclusion}

The present-day Tripuris, particularly those staying in urban or semi-urban areas are commonly influenced by the Hindu Succession Act. As an outcome, the womenfolk are also entitled to inherit an equal share with their counterparts. But in rural areas, family members sit together and distribute the land among the offspring. In our study, we observed that most rural women consider the provision of equal share on ancestral property to be in favour of women, but at the same time they also said that traditional thinking continues to prevail such that women should not have property or they cannot be a property owner. This societal perception prevents women from demanding their legitimate share of their ancestral property.

In conclusion, the affirmative action by the state has enabled the Tripuri women to become owners of land or property, particularly in areas which are economically backward and remote. In the advanced areas, age-old tribal practices are on the wane in the wake of modernization. Gradually, Tripuri women are becoming aware of their constitutional rights. However, deeply-entrenched prejudices against giving rightful share to the women in parental property continue to be evident in the Tripuri community.

\section{References}

Agarwal, B. (1994). A field of one's own. New Delhi: Cambridge University Press India.

- (2003). Gender and land rights revisited: exploring new prospects via the state, family and market. Journal of Agrarian Change, 3 (1, 2), pp. 184-224.

Agnes, F. (2009). Conjugality, property, morality and maintenance. Economic and Political Weekly, XLIV (44), pp. 58-64.

Amaral, S. (2017). Do improved property rights decrease violence against women in India? (No. 2017-13). ISER Working Paper Series.

Annual Report (2013-14). Tripura Commission for Women and National Commission for Women. Tripura.

Anurupa Devi (1949). Women in literature: creators and their creations. University of Calcutta, Calcutta.

Barman, D. (1983). Treatise on traditional social institutions of the Tripuri community, Agartala: Directorate of Research, Department of Welfare for Sch. Tribes \& Sch. Castes, Govt. of Tripura.

Barooah, J. (2009). Customary laws of the Tripuris of Tripura. Guwahati: Labanya Press.

Bhowmik, D.L. (2003). Tribal religion of Tripura: a socio-religious analysis. Agartala: Tribal Research Institute, Government of Tripura.

Census of India. (2011). Census of India 2011 provisional population totals. New Delhi: Office of the Registrar General and Census Commissioner. 
Hilliard, Starr, et al. Perceived impact of a land and property rights program on violence against women in rural Kenya: A qualitative investigation. Violence against women. 22.14 (2016), pp. 1682-1703.

Kabeer, N. (2000). Social exclusion, poverty and discrimination towards an analytical framework. IDS bulletin, 31(4), pp. 83-97.

Kelkar, G. (2014). The fog of entitlement women's inheritance and land rights, Economic and Political Weekly, 49(33), pp. 51-58.

Lahoti, R., \& Swaminathan, H. (2016). Economic development and women's labor force participation in India. Feminist Economics, 22(2), pp. 168-195.

Majumdar, R. (2003). History of women's rights: a non-historicist reading. Economic and Political Weekly, 38(22), pp. 2130-2134.

National Family Health Survey 4. (2015-16). Ministry of Health and Family Welfare. Government of India.

Panda, P., \& Agarwal, B. (2005). Marital violence, human development and women's property status in India. World Development, 33(5), pp. 823-850.

Rao, N. (2005). Women's rights to land and assets: Experience of mainstreaming gender and development project. Economic and Political Weekly, 40(44/45), pp. 4701-4708.

- (2017). Good women do not inherit land: politics of land and gender in India. Routledge Publication.

Silver, H. (2011). Social exclusion \& solidarity: three paradigms. Critical Quest: New Delhi.

Thorat, S. (2013). Caste, social exclusion and poverty: concept, measurement \& empirical evidence. Critical Quest: New Delhi.

Tripura Commission for Women and National Commission for Women (2006), Land Rights of Women in Tripura. A monograph based on a research study, New Delhi. 